\title{
GOOD UNIVERSITY GOVERNANCE UNTUK MENINGKATKAN EXCELLENT SERVICE DAN KEPERCAYAAN MAHASISWA (Studi Kasus Fakultas Ekonomi Universitas Semarang)
}

\author{
Kesi Widjajanti \\ Eviatiwi Kusumaningtyas Sugiyanto
}

\begin{abstract}
Abstrak
Tujuan dari penelitian ini adalah menganalisis dampak dari implementasi good university governace (GUG) dalam upaya peningkatan excellent service dan kepercayaan mahasiswa (Trust) di Fakultas Ekonomi Universitas Semarang. 225 responden digunakan untuk memberikan tanggapan pelaksanaan GUG, excellent service dan memberikan penilaian tingkat kepercayaannya terhadap Fakultas. Alat analisis yang digunakan adalah metode student satisfaction index (SSI) dan structural equation modeling (SEM). Dengan menggunakan metode SSI ditemukan atribut layanan yang menjadi sasaran perbaikan kualitas layanan di FE USM yaitu efektifitas pembelajaran tentang kemudahan untuk bertemu dosen diluar kelas selama jam kerja dan pelayanan fasilitas (layanan sarana dan prasarana): kondisi sarana ibadah dan toilet di FE USM. Sedangkan hasil Analisis SEM menunjukkan bahwa GUG berpengaruh positif signifikan terhadap Excellent Service dan Excellent Service berpengaruh positif signifikan terhadap Trust. GUG secara langsung tidak berpengaruh terhadap Trust. Hal ini berarti bahwa pelaksanaan tata kelola universitas yang baik (GUG) tidak dapat langsung memberikan kepercayaan (Trust) terhadap mahasiswa tanpa adanya bukti nyata yang dapat dirasakan yaitu pelayanan yang prima (Excellent Service).
\end{abstract}

Kata Kunci: Good University Governance, Excellent Service, Trust

\begin{abstract}
The purpose of this research was to analyzed and to find an empiric proof, that excellent service and trust could be improved by the implementation of good university governance $(G U G)$ at The Economics Faculty of Semarang University. 225 respondent used to provide feedback of GUG and excellent service implementation on the faculty by filling the quetionnaire. The respondent also provide an assessment of their trust level to the faculty. This research use Student Satisfaction Inventory (SSI) dan Structural Equation Model (SEM) method to analyze the result of the questionnaire. SSI method found that effectiveness of learning about the ease to meet lecture outside the classroom during the working hours and service facilities (infrastructural service): the condition of mosque and toilet will be prioritized for enhanced service quality. While the result of SEM analysis showed that GUG had a significant positive effect toward excellent service and excellent service had a significant positive effect toward trust. GUG directly had no significant effect toward trust. It means that GUG could not directly provide the trust of the student without real evidence that could be percieved, excellent services.
\end{abstract}

Keywords: Good University Governance, Excellent Service, Trust

\section{PENDAHULUAN}

Meningkatnya kebutuhan masyarakat akan pendidikan dalam hal ini pendidikan tinggi menjadi peluang tersendiri bagi perguruan tinggi, khususnya perguruan tinggi swasta (PTS) untuk berlomba-lomba menarik minat masyarakat agar memilih institusinya. Namun persaingan PTS dalam memperebutkan pasar mahasiswa ini cukup berat. Jumlah Perguruan Tinggi yang ada di Indonesia 
mencapai 3.151 Perguruan Tinggi (PT). Dari banyaknya Perguruan Tinggi tersebut sebanyak 3.068 atau $97 \%$ merupakan PTS, sedangkan PTN hanya berjumlah 83 atau 3\% (APTISI, 2014).

Ditengah persaingan yang cukup berat, peningkatan mutu menjadi hal yang tidak terhindarkan agar dapat bersaing mendapat kepercayaan masyarakat dan tetap eksis. Perguruan tinggi dituntut untuk dapat memberikan pelayanan yang sebaik-baiknya kepada masyarakat dan berorientasi kepada kebutuhan masyarakat. Layanan akademik berikut fasilitas pendukungnya menjadi salah satu pertimbangan calon mahasiswa dalam memilih perguruan tinggi untuk melanjutkan pendidikannya. Sehingga kualitas layanan menjadi salah satu indikator dari keberhasilan institusi pendidikan sebagai sebuah organisasi publik.

Universitas Semarang (USM) merupakan salah satu PTS yang ada di Semarang Jawa Tengah, berdiri pada tahun 1987. Untuk dapat eksis seperti sekarang diperlukan suatu perbaikan kinerja yang terus menerus dalam melayani masyarakat, mengingat ada sekitar 240 PTS di Jawa Tengah. FE USM berusaha memberikan pelayanan sebaik mungkin sesuai dengan ekspektasi konsumen (mahasiswa) dengan meningkatkan kualitas pelayanan terutama kualitas pelayanan akademik sebagai core business dari perguruan tinggi.

Salah satu upaya yang dilakukan FE USM adalah dengan menerapkan prinsip Good University Governance (GUG) dalam tata kelola Fakultas menuju peningkatan mutu yang berkelanjutan. GUG adalah suatu sistem tata kelola universitas yang baik dengan menganut prinsip-prinsip dari good governance yaitu transparansi, akuntabilitas, partisipasi, equity, dsb. Imple- mentasi GUG diharapkan dapat mewujudkan excellent service terutama dalam pelayanan akademik. Excellent service adalah pelayanan yang tidak hanya memenuhi harapan pelanggan tetapi juga melebihi harapan dari pelanggan. Excellent service tersebut dapat menjadi modal untuk meningkatkan kepercayaan masyarakat (mahasiswa) terhadap Fakultas Ekonomi. Hal ini sejalan dengan argumen Nurcahyani, 2012 yang menerangkan bahwa penerapan prinsip good corporate governance secara konsisten dan berkesinambungan, dapat menghasilkan suatu kepercayaan publik.

Surya dalam Dalimunthe (2010) menjelaskan bahwa mutu dan kualitas pelayanan menjadi lebih baik dan memuaskan dan tidak menimbulkan keluhan masyarakat dalam menerima pelayanan setelah adanya penerapan prinsip-prinsip good corporate governance. Namun dari hasil survei pendahuluan yang dilakukan kepada 100 mahasiswa FE USM, didapati ada beberapa keluhan yang memperlihatkan bahwa pelayanan yang diberikan belum maksimal. Adapun hal yang dimaksud dapat ditunjukkan dalam tabel 1 di bawah ini.

Tabel 1

Hasil Survei Pendahuluan Keluhan Mahasiswa

\begin{tabular}{|l|l|c|}
\hline No. & \multicolumn{1}{|c|}{ Jenis Keluhan } & Jumlah \\
\hline 1. & Akademik & 4 \\
\hline 2. & Kemahasiswaan & 2 \\
\hline 3. & $\begin{array}{l}\text { Evaluasi Hasil Belajar \& } \\
\text { Penilaian }\end{array}$ & 25 \\
\hline 4. & Fasilitas & 37 \\
\hline 5. & Personel Dosen (kinerja & 2 \\
\hline 6. & $\begin{array}{l}\text { Lain-lain } \\
\text { karyawan: front liner) }\end{array}$ \\
\hline 7. & Tidak ada Keluhan & 13 \\
\hline & Jumlah & 100 \\
\hline
\end{tabular}

Sumber: Survei Pendahuluan (2014) 
Survei pendahuluan dilakukan dengan memberikan pertanyaan terbuka tentang keluhan (ketidakpuasan) dalam pelayanan yang dirasa oleh mahasiswa FE USM. Dari hasil tersebut terlihat bahwa 3 (tiga) keluhan terbesar yaitu dalam pemberian layanan fasilitas (sarana dan prasarana), evaluasi hasil belajar \& penilaian serta personel dosen. Keluhan-keluhan yang ditulis mahasiswa antara lain tempat ibadah yang tidak representatif, toilet yang tidak bersih, ruang kelas yang sering kotor, suara gemuruh dari Gelora USM, tidak lengkapnya buku-buku diperpustakaan, susahnya mendapat nilai "A" dalam mata kuliah, fasilitas wifi yang tidak memadai, dosen yang tidak ramah dan hanya menyuruh membuat ringkasan tanpa menerangkan, serta tidak ada konfirmasi menyangkut kehadiran dosen, dsb.

Dari survei pendahuluan tersebut menarik untuk diteliti tentang sejauh mana keberhasilan penerapan good university governance di FE USM dalam mewujudkan excellent service dan menciptakan kepercayaan mahasiswa. Selain melihat pengaruh implementasi dari good university governance, dalam penelitian ini juga akan menganalisis tingkat kepuasan yang dirasakan mahasiswa dan tingkat kepentingan dari tiap dimensi pelayanan akademik yang diberikan oleh FE USM. Sehingga selain dapat menganalisis seberapa jauh implementasi good university governance dalam meningkatkan excellent service dan kepercayaan terhadap mahasiswa, dengan menggunakan student statisfaction inventory diketahui pula tingkat kepuasan dan tingkat kepentingan dari dimensi pelayanan akademik yang dirasakan oleh mahasiswa yang nantinya dapat menjadi focus perbaikan pelayanan.
Rumusan masalah dalam penelitian ini adalah bagaimana meningkatkan excellent service dan trust melalui penerapan prinsip-prinsip good university governance

Teori ekpektansi (expectancy theory) menurut Victor Vroom yang dikutip oleh Antarwiyati (2006) didasarkan pada ide bahwa tiap orang memiliki ekspektansi (harapan yang kuat). Jika suatu objek mendukung dalam pencapaian tujuan, maka suatu individu akan menunjukan sikap senang terhadap objek tersebut. Universitas atau dalam hal ini Fakultas sebagai penyedia jasa, atau pemberi layanan dalam mencapai gelar akademis, dan mahasiswa sebagai stakeholder utama penerima layanan akan memberikan sifat positif yaitu kepercayaan terhadap Universitas/ Fakultas jika pelayanan yang diberikan sesuai atau bahkan melebihi harapan yang ada.

Good Governance merupakan bentuk dari penyelenggaraan suatu organisasi untuk mencapai tujuan berdasarkan prinsip-prinsip tata kelola yang baik. Dalimunthe (2010) menggunakan prinsip transparansi, akuntabilitas, keadilan, dan partisipasi sebagai indikator Good Governance

Sentana (2006) dan Rahmayanty (2010) mengemukakan service excellence adalah pelayanan yang sangat baik dan melampaui harapan pelanggan, pelayanan yang memiliki ciri khas kualitas (quality nice), pelayanan dengan standar mutu yang tinggi dan selalu mengikuti perkembangan kebutuhan pelanggan. Layanan utama yang diberikan oleh sebuah perguruan tinggi adalah layanan akademik. Layanan akademik tersebut antara lain:

1. Efektivitas Pembimbingan Akademik

2. Efektivitas Pembelajaran 
3. Efektivitas Layanan Administrasi

4. Focus Terhadap Mahasiswa

5. Efektivitas Layanan Sarana dan Prasarana Pendukung

Kepercayaan adalah kesediaan pihak tertentu menjalin kemitraan dengan pihak lain dengan dasar keyakinan dan tanggung jawab. Kepercayaan sebagai keyakinan mahasiswa akan kualitas dan keandalan pelayanan yang ditawarkan oleh perguruan tinggi. menurut Mayers dalam Putri (2012) faktor yang membentuk kepercayaan seseorang terhadap yang lain ada tiga yaitu kemampuan (ability), kebaikan hati (benevolence), dan integritas (integrity).

Hubungan Good University Governance terhadap Excellent Service Penerapan prinsip-prinsip Good University Governance (GUG) dalam pengelolaan pelayanan menjadi suatu tuntutan utama terhadap peningkatan kinerja pelayanan. Surya dalam Dalimunthe (2010) menjelaskan bahwa mutu dan kualitas pelayanan menjadi lebih baik dan memuaskan dan tidak menimbulkan keluhan masyarakat dalam menerima pelayanan setelah adanya penerapan prinsip-prinsip good corporate governance.

H1 : Penerapan GUG berpengaruh positif terhadap Excellent service

Hubungan Good University

Governance terhadap Trust

Penerapan Good Corporate Governance (GCG) pada perusahaan merupakan suatu konsep yang digunakan guna menjaga konsistensi dan kepercayaan masyarakat terhadap perusahaan. Penerapan prinsip good corporate governance secara konsisten dan berkesinambungan, dapat menghasilkan suatu kepercayaan publik (Nurcahyani, 2012). Kepercayaan terhadap kemampuan institusi muncul karena dalam penerapan good governance ada pem- bagian wewenang dan tanggung jawab yang jelas diantara peserta yang terlibat, serta sesuai dengan kompetensi masingmasing.

H2 : Penerapan GUG berpengaruh positif terhadap trust

Hubungan Excellent Service terhadap Trust

Keyakinan merupakan hal pokok dalam kepercayaan. Garbarino dan Jhonson dalam Jahroni (2009), menyatakan bahwa kepercayaan sebagai keyakinan konsumen akan kualitas dan keandalan pelayanan yang ditawarkan oleh suatu organisasi. Kepercayaan pihak tertentu terhadap yang lain dalam melakukan hubungan transaksi didasarkan atas suatu keyakinan bahwa orang yang dipercayainya tersebut memiliki segala kewajibannya secara baik sesuai yang diharapkan dalam konteks ini memiliki pelayanan yang baik.

H3 : Pelaksanaan Excellent Service berpengaruh positif terhadap Trust

Dari hubungan logis antar variabel tersebut dapat disusun kerangka penelitian sebagai berikut:

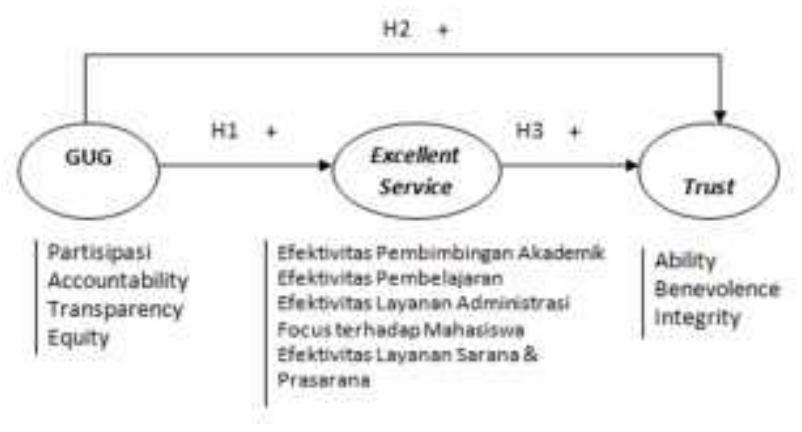

Gambar 1

Kerangka Penelitian

\section{METODE PENELITIAN}

\section{Populasi dan Sampel}

Populasi dalam penelitian ini adalah mahasiswa FE USM yang telah 
menempuh kuliah minimal tiga semester. Sampel ditentukan dengan menggunakan nonprobability sampling yaitu dengan metode kuota sampling. Berdasarkan metode tersebut diperoleh 225 sampel (15 x jumlah parameter).

\section{Pengukuran Variabel Penelitian}

Variabel Good University Governance Variabel eksogen Good University Governance diukur dengan menggunakan 7 indikator yaitu X1: kesempatan berpartisipasi, X2: kemauan berpartisipasi, X3: Akuntabilitas program layanan, X4: Akuntabilitas Prosedur Layanan, X5: Keterbukaan Informasi, X6: Non Diskriminasi dan X7: Kesesuaian dengan hukum dan peraturan.

\section{Variabel Excellent Service}

Variabel endogen excellent service diukur dengan menggunakan lima indikator yaitu Y1: efektivitas pembimbingan akademik, Y2: efektivitas pembelajaran, Y3: efektivitas pelayanan administrasi, Y4: focus terhadap mahasiswa dan Y5: efektivitas layanan sarana dan prasarana.

\section{Variabel Trust}

Variabel endogen kepercayaan diukur dengan menggunakan tiga indikator yaitu Y6: kemampuan (ability), Y7: kebaikan hati (benevolence), dan Y8: integritas (integrity).

\section{Teknik Analisis}

\section{Analisis Deskriptif}

Selain menggunakan distribusi frekuensi dan rata-rata (mean), metode lain yang digunakan dalam analisis deskriptif adalah Student Statisfaction Inventory (SSI) yang mengukur tingkat kualitas layanan berdasarkan tingkat kepuasan dan tingkat kepentingan dari setiap dimensi yang ada di SSI (Levitz, 2005).

\section{Analisis Structural Equation Modeling (SEM)}

Digunakan untuk menguji variabel eksogen $(G U G)$ terhadap variabel endogen (Excellent Service dan Trust).

\section{HASIL PENELITIAN Analisis Deskriptif}

Tabel 2

Frekuensi Jawaban Responden

\begin{tabular}{|c|c|c|c|}
\hline \multirow{2}{*}{ Indikator } & \multirow{2}{*}{$\begin{array}{l}\text { Rata- } \\
\text { Rata } \\
\text { Skor }\end{array}$} & \multicolumn{2}{|c|}{$\begin{array}{c}\text { Frekuensi Jawaban } \\
\text { Responden (\%) }\end{array}$} \\
\hline & & $\begin{array}{l}\text { Memberi } \\
\text { Skor 1-5 }\end{array}$ & $\begin{array}{l}\text { Memberi } \\
\text { Skor 6-10 }\end{array}$ \\
\hline $\mathrm{X} 1$ & 5.62 & 50,6 & 49,4 \\
\hline$x 2$ & 4.50 & 68,0 & 32,0 \\
\hline$x 3$ & 5.97 & 38,6 & 61,3 \\
\hline$X 4$ & 6.41 & 29,3 & 70,7 \\
\hline$\times 5$ & 6.38 & 33,8 & 66,3 \\
\hline$x 6$ & 7.04 & 23,1 & 76,9 \\
\hline$x 7$ & 7.20 & 16,4 & 83,5 \\
\hline $\mathrm{Y} 1$ & 6.62 & 27,1 & 72,9 \\
\hline Y2 & 6.52 & 26,6 & 73,4 \\
\hline Y3 & 6.13 & 37,3 & 62,7 \\
\hline Y4 & 6.76 & 25,3 & 74,6 \\
\hline Y5 & 6.65 & 26,6 & 73,4 \\
\hline Y6 & 7.14 & 15,5 & 84,4 \\
\hline Y7 & 6.92 & 17,3 & 82,6 \\
\hline Y8 & 7.00 & 17,7 & 82,2 \\
\hline
\end{tabular}

Skala penilaian 1-10 dalam kuesioner menunjukkan bahwa semakin besar angka yang diberikan responden, semakin bagus pula penilaian dari responden terhadap indikator-indikator yang dimplementasikan di FE USM. Mahasiswa menilai pelaksanaan $G U G$ di FE USM telah berjalan baik (X1-X7) kecuali X2. Rendahnya nilai rata-rata kemauan berpartisipasi (X2) menunjukkan bahwa kesadaran mahasiswa untuk aktif terlibat dalam setiap kesempatan 
berpartisipasi untuk perbaikan kualitas layanan akademik masih rendah. Selama ini mahasiswa telah terbiasa menerima kebijakan pelayanan tanpa mempertanyakan kebijakan tersebut. Sehingga, ketika kesempatan berpartisipasi dibuka, sulit bagi mereka untuk mengubah pola pemikiran yang telah ada. Alasan yang lain mahasiswa tidak mengetahui adanya kesempatan untuk berpartisipasi dan mahasiswa tidak mengetahui prosedur berpartisipasi, sehingga mereka enggan untuk berpartisipasi. Selanjutnya berdasarkan nilai rata-rata dan frekuensi pada variabel eksogen yaitu excellent service (Y1-Y5) dan trust (Y6-Y8), menunjukkan bahwa mahasiswa menilai pelayanan akademik yang diberikan telah berjalan baik serta kepercayaan mahasiswa terhadap fakultas cukup tinggi.

Sedangkan analisis deskritif dengan menggunakan SSI menunjukkan hasil sebagai berikut:

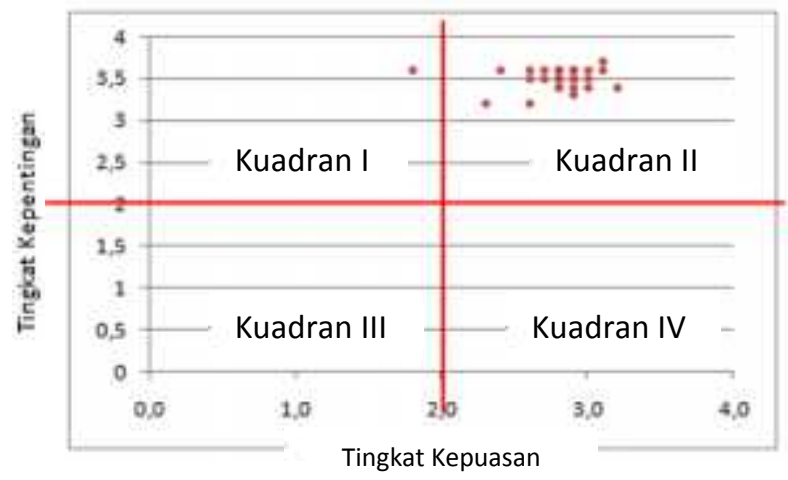

Gambar 2

\section{Importance-Satisfaction Matrix}

Tiga puluh empat dimensi atau atribut layanan digunakan untuk mengukur tingkat kepuasan dan derajat kepentingan dari setiap item pelayananan yang dilaksanakan di $\mathrm{FE}$ USM. Dari gambar terlihat bahwa 33 atribut masuk dalam kuadran II yang berarti dimensi layanan atau atributatribut kualitas layanan dianggap penting oleh mahasiswa dan atribut kualitas layanan tersebut sudah sesuai dengan harapan mahasiswa. Namun ada satu atribut layanan yang masuk dalam Kuadran I, atribut tersebut dianggap penting oleh mahasiswa tetapi kualitas layanannya belum sesuai dengan harapan mahasiswa. Atribut tersebut adalah pelayanan fasilitas (layanan sarana dan prasarana) tepatnya adalah kondisi toilet di FE USM. Atribut ini menjadi kelemahan kualitas layanan di FE USM dan menjadi sasaran perbaikan layanan. Selain itu, meskipun dapat digolongkan masuk dalam kategori II, ada dua atribut layanan yang memiliki nilai tingkat kepentingan tinggi namun dirasa cukup memiliki tingkat kepuasan. Atribut tersebut yaitu efektifitas pembelajaran tentang kemudahan untuk bertemu dosen diluar kelas selama jam kerja dan pelayanan fasilitas (layanan sarana dan prasarana): Kondisi sarana ibadah di fakultas.

\section{Analisis Structural Equation Model}

Hasil run pertama terhadap model menunjukkan bahwa model dinyatakan tidak memenuhi kriteria fit. Sehingga dilakukan reformulasi pada model dengan menghilangkan indikator yang memiliki nilai Squared Multiple Correlations yang terendah dan loading faktor kurang dari 0,5 yaitu X2 dan X6.

\section{Penilaian Model Fit setelah Reformulasi Model}

Tabel 3

Hasil Pengujian Kelayakan Model

\begin{tabular}{|c|c|c|c|}
\hline $\begin{array}{c}\text { Goodness of } \\
\text { Fit Indices }\end{array}$ & Cut off & Hasi Estimasi & Keputusan \\
\hline RMSEA & $0,05-0,08$ & 0,082 & Marginal Fit \\
\hline NFI & $0,00-1,00$ & 0,890 & Margnal Fit \\
\hline CFI & $0,00-1,00$ & 0,931 & Model Fit \\
\hline RFI & $0,00-1,00$ & 0,861 & Marginal Fit \\
\hline IFI & $0,00-1,00$ & 0,931 & Model Fit \\
\hline TH & $0,00-1,00$ & 0,912 & Model Fit \\
\hline
\end{tabular}




\begin{tabular}{|c|c|c|c|c|}
\hline Konstruk & Indikator & Loading & $1-\lambda^{2}$ & CR \\
\hline \multirow{6}{*}{ GUG } & $\mathrm{X} 1$ & 0,514 & 0,736 & \\
\hline & $\mathrm{X3}$ & 0,799 & 0,362 & \\
\hline & X4 & 0,852 & 0,274 & \\
\hline & $\mathrm{X5}$ & 0,702 & 0,507 & \\
\hline & $x 7$ & 0,524 & 0,725 & \\
\hline & & 3,391 & 2,604 & 0,81535 \\
\hline \multirow{6}{*}{$\begin{array}{c}\text { Excellent } \\
\text { Service }\end{array}$} & Y1 & 0,668 & 0,554 & \\
\hline & Y2 & 0,731 & 0,466 & \\
\hline & Y3 & 0,728 & 0,470 & \\
\hline & Y4 & 0,577 & 0,667 & \\
\hline & Y5 & 0,577 & 0,667 & \\
\hline & & 3,281 & 2,824 & 0,792209 \\
\hline \multirow{4}{*}{ Trust } & Y6 & 0,803 & 0,355 & \\
\hline & Y7 & 0,822 & 0,324 & \\
\hline & Y8 & 0,828 & 0,314 & \\
\hline & & 2,453 & 0,994 & 0,858236 \\
\hline
\end{tabular}

Uji Validitas Konstruk Convergent Validity

Tabel 4

Hasil Output Standardized Loading Estimate

\begin{tabular}{|c|c|c|c|}
\hline Konstruk & Indikator & Loading & CR \\
\hline \multirow{4}{*}{ GUG } & $\mathrm{X} 1$ & 0,514 & \\
\cline { 2 - 4 } & $\mathrm{X} 3$ & 0,799 & 7,569 \\
\cline { 2 - 4 } & $\mathrm{X} 4$ & 0,852 & 7,628 \\
\cline { 2 - 4 } & $\mathrm{X} 5$ & 0,702 & 7,026 \\
\cline { 2 - 4 } & $\mathrm{X} 7$ & 0,524 & 5,865 \\
\hline \multirow{4}{*}{$\begin{array}{c}\text { Excellent } \\
\text { Service }\end{array}$} & $\mathrm{Y} 1$ & 0,668 & 7,641 \\
\cline { 2 - 4 } & $\mathrm{Y} 2$ & 0,731 & 8,11 \\
\cline { 2 - 4 } & $\mathrm{Y} 3$ & 0,728 & 8,128 \\
\cline { 2 - 4 } & $\mathrm{Y} 4$ & 0,577 & 6,846 \\
\cline { 2 - 4 } & $\mathrm{Y} 5$ & 0,577 & \\
\hline \multirow{3}{*}{ Trust } & $\mathrm{Y} 6$ & 0,803 & \\
\cline { 2 - 4 } & $\mathrm{Y} 7$ & 0,822 & 12,906 \\
\cline { 2 - 4 } & $\mathrm{Y} 8$ & 0,828 & 13,623 \\
\hline
\end{tabular}

Berdasarkan hasil output standardized loading estimate di atas, semua nilai loading di atas 0,5 dan menunjukkan hasil yang signifikan, yaitu nilai dengan $\mathrm{CR}$ diatas 1,96 sehingga syarat convergent validity terpenuhi.

\section{Construct Reliability}

Berdasarkan tabel di bawah seluruh nilai reliabilitas dari konstruk menunjukkan nilai > 0,70 sehingga dapat dikatakan konstruk reliabel
Tabel 5

Hasil Perhitungan Construct Reliability

\section{Pengujian Hipotesis}

Tabel 6

Persamaan Struktural

\begin{tabular}{|l|l|l|}
\hline & Hipotesis 1 & Hipotesis 2 \&3 \\
\hline Persamaan & $\eta 1=0,677 \xi_{1}+$ & $\begin{array}{l}\eta=0,051 \xi_{1}+ \\
0,877 \eta 1+\zeta 1\end{array}$ \\
\hline $\mathbf{R}^{\mathbf{2}}$ & $\zeta_{1}$ & 0,833 \\
\hline
\end{tabular}

Nilai Critical Ratio (CR)

GUG $\rightarrow$ excellent Service $=5,470$

GUG $\rightarrow$ Trust $=0,593$

Excellent Service $\rightarrow$ Trust $=6,781$

\section{H1: Penerapan GUG berpengaruh positif terhadap Excellent service} Nilai CR > 1,96 dan persamaan struktural yang bertanda positif menunjukkan bahwa GUG berpengaruh positif terhadap excellent service. Nilai $R^{2}$ sebesar 0,44 berarti bahwa variabel GUG mampu menjelaskan variasi variabel excellent service sebesar $44 \%$.

\section{H2: Penerapan $G U G$ berpengaruh positif terhadap Trust}

Nilai CR < 1,96 menunjukkan bahwa Good university governance tidak berpengaruh secara langsung terhadap trust.

H3: Pelaksanaan Excellent Service berpengaruh positif terhadap Trust

Nilai CR > 1,96 dan persamaan struktural yang bertanda positif menunjukkan bahwa excellent service berpengaruh positif terhadap trust. Nilai $R^{2}$ sebesar 0,833 memiliki arti bahwa variabel GUG dan excellent service 
mampu menjelaskan variasi variabel trust sebesar 83,3\%. Dari koefisien regresi diketahui pula hubungan tidak langsung variabel GUG terhadap trust, melalui excellent service. Pengaruh tidak langsung sebesar $0,5849(0,677 \times 0,877)$ lebih besar dari pengaruh langsung dengan koefisien regresi sebesar 0,051. Hal tersebut menunjukkan bahwa excellent service memediasi hubungan antara GUG dengan trust.

\section{Pembahasan}

\section{Good University Governance berpengaruh positif signifikan terhadap excellent service}

Surya dalam Dalimunthe (2010) menjelaskan bahwa mutu dan kualitas pelayanan menjadi lebih baik dan memuaskan dan tidak menimbulkan keluhan masyarakat dalam menerima pelayanan setelah adanya penerapan prinsip-prinsip good corporate governance. Terwujudnya pelayanan publik yang berkualitas merupakan salah satu ciri good governance. Veronika dalam Linda (2012) mengungkapakan bahwa pelaksanaan prinsip-prinsip good governance berpengaruh sangat tinggi terhadap pelayanan publik. Menurut Meier dalam Armunanto (2005) good governance merupakan cara mengatur pemerintahan yang memungkinkan layanan publiknya efisien, sistem pengendaliannya bisa diandalakan dan administrasinya bertanggung jawab terhadap publik. Dari beberapa pernyataan tersebut penerapan good governance, good corporate governance ataupun good university governance dapat memberikan pengaruh yang positif terhadap pelayanan di suatu organisasi.

Partisipasi yang semakin luas akan berkontribusi kepada dua hal, yaitu terhadap pertukaran informasi yang diperlukan bagi pengambilan keputusan, dan untuk memperkuat keabsahan atau legitimasi atau berbagai keputusan yang ditetapkan. Tingkat legitimasi keputusan yang kuat pada gilirannya akan mendorong efektivitas pelaksanaan (Kasmawati, 2012). Partisipasi sangat bermanfaat dalam meningkatkan kualitas pelayanan, dari bentuk partisipasi yang paling sederhana yaitu penyampaian keluhan atau dalam bentuk partisipasi yang lebih tinggi yaitu terlibat secara langsung dalam tahap perencanaan sampai dengan pemantau dan evaluasi. Partisipasi dapat menjadi sarana untuk perbaikan atau peningkatan kualitas pelayanan publik.

Menurut Armunto (2005), Akuntabilitas adalah bagaimana pelayanan berorientasi pada pelanggan sehingga pelanggan merasa puas. Lebih lanjut Armanto menjelaskan bahwa organisasi yang memiliki akuntabilitas tinggi dalam pelayanan, akan selalu memenuhi standar pelayanan pelanggan yang telah ditetapkan.

Dwiyanto (2006) mengemukakan bahwa jika tidak adanya transparansi dalam birokrasi pelayanan public, maka banyak masyarakat yang akan mengalami frustrasi. Salah satu indikasi tidak adanya transparansi dalam birokrasi pelayanan publik ialah faktor komunikasi tidak efektif. Komunikasi yang tidak efektif akan menurunkan kualitas pelayanan karena dapat merusak informasi yang dibutuhkan masyarakat misalnya informasi tidak tepat waktu, kurang jelas, kurang lengkap dsb. Jadi komunikasi efektif sebagai wujud transaparansi merupakan hal yang sangat berperan terhadap keberhasilan suatu pelayanan. Maka semakin baiknya penerapan prinsip transparansi, maka pelayanan yang diberikan akan semakin baik. 
Menurut Setyorini (2012) keadilan dapat dilihat dari sudut pandang interaksional antara pemberi layanan dan penerima layanan. Keadilan dalam hal perlakuan interpersonal yang diterima seseorang selama menerima layanan. Perlakuan interpersonal yang adil mencerminkan kesantunan, perhatian dan kejujuran akan sama baiknya dengan ketepatan atas penjelasan dan usaha sungguh-sungguh dalam memberikan pelayanan sesuai aturan. Sehingga semakin baik implementasi keadilan dalam memberikan layanan akan semakin baik pula kualitas layanan yang dihasilkan.

\section{Good University Governance tidak berpengaruh terhadap trust}

Terselenggaranya good university governance merupakan prasyarat utama untuk mewujudkan aspirasi mahasiswa, namun hal tersebut tidak langsung memberikan kepercayaan mahasiswa. Kepercayaan timbul karena adanya interkasi antara trustee dan trustor (Nasution, 2007). Interaksi ini terjadi ketika trustor menkonsumsi jasa dari trustee.

Prinsip-prinsip GUG merupakan sebuah janji yang membawa harapan mahasiswa terhadap fakultas. Harapan tersebut akan berkembang menjadi kepercayaan yang tinggi atau semakin hilang nilainya manakala telah terjadi interaksi yaitu mahasiswa menilai harapannya dengan kenyataan yang ada (pelayanan yang diterimanya). Penerapan prinsip-prinsip GUG tidak akan memberikan pengaruh terhadap kepercayaan sebelum mahasiswa merasakan bukti dari pelaksanaan janji tersebut.

Lebih lanjut Rod dan Anthony Jacks dalam Garniska (2014) mengatakan bahwa kepercayaan pelanggan terhadap perusahaan diimplementasikan dari kredibilitas perusahaan dan kepedulian perusahaan pada pelanggan yang ditunjukan melalui performance perusahaan. Yang berarti bahwa kepercayaan mahasiswa terhadap fakultas diimplementasikan dari kredibilitas dan kepedulian Fakultas melalui performance perusahaan yaitu excellent service. Jadi penerapan prinsip-prinsip GUG tidak dapat secara langsung memberikan kepercayaan terhadap mahasiswa namun mahasiswa akan merasakan terlebih dahulu penerapan prinsip-prinsip tersebut tindakantindakan nyata melalui excellent service yang diberikan.

\section{Excellent Service berpengaruh positif signifikan terhadap trust}

Menurut Ove dan Albinson dalam Garniska (2014) menjelaskan bahwa kepercayaan timbul karena adanya suatu rasa percaya kepada pihak lain yang memang memiliki kualitas. Excellent service merupakan bentuk kualitas organisasi jasa yang dapat menciptakan kepercayaan. Menurut Singh dan Sirdeshmukh dalam Nasution (2007) menjelaskan bahwa pembentukan kepercayaan sudah dimulai sebelum sesorang menerima jasa. Kadar atau tingkat kepercayaan pada fase ini masih sangat kecil. Setelah proses konsumsi jasa selesai tingkat kepercayaan menjadi berubah. Pengalaman yang positif saat mengkonsumsi jasa akan meningkatkan kepercayaan, sementara pengalaman yang negatif akan menurunkan kepercayaan. Dari pernyataan tersebut dapat diartikan bahwa kepercayaan sangat tergantung pada kualitas jasa yang diberikan, semakin bagus pelayanan maka semakin tinggi pula kepercayaan yang diberikan. 


\section{KESIMPULAN DAN SARAN}

\section{Kesimpulan}

1) Gambaran implementasi good university governance, pelaksanaan excellent service serta penilaian tingkat kepercayaan mahasiswa terhadap FE Universitas Semarang

- Mahasiswa menilai pelaksanaan Good University Governance di FE USM telah berjalan baik. Dalam pelaksanaan GUG yang masih dirasa kurang adalah dalam partisipasi mahasiswa atau kemauan mahasiswa untuk aktif terlibat dalam setiap kesempatan berpartisipasi untuk perbaikan kualitas layanan akademik di FE USM.

- Untuk pelaksanaan excellent service, secara garis besar mahasiswa menilai pelayanan akademik di FE USM telah memenuhi harapan mereka. Namun setelah dilakukan penelusuran secara rinci dengan menggunakan atribut-atribut kualitas layanan pada analisis SSI (student satisfaction index) ditemukan bahwa pelayanan yang menjadi fokus perbaikan adalah pelayanan pada fasilitas yaitu toilet. Karena atribut tersebut dirasa penting oleh mahasiswa namun masih kurang dalam pelayanannya. Hal ini sejalan dengan hasil survei pendahuluan keluhan mahasiswa yang menunjukkan keluhan paling banyak yaitu pada fasilitas penunjang (sarana dan prasarana) khususnya toilet

- Pada excellent service atribut layanan yang perlu ditingkatkan lagi adalah efektifitas pembelajaran tentang kemudahan untuk bertemu dosen di luar kelas selama jam kerja dan pelayanan fasilitas (layanan sarana dan prasarana): Kondisi sarana ibadah di fakultas.

- Untuk kepercayaan, mahasiswa memberikan penilaian yang baik artinya mahasiswa yakin dan percaya bahwa FE USM memiliki kamampuan, perhatian dan integritas untuk memberikan pelayanan yang sesuai dengan kebutuhan dan harapan mahasiswa.

2) Pengaruh implementasi good university governance terhadap excellent service dan trust

- Masalah penelitian telah terjawab bahwa pelaksanaan tata kelola universitas yang baik tidak dapat langsung memberikan kepercayaan terhadap mahasiswa tanpa adanya bukti nyata yang dapat dirasakan yaitu pelayanan yang excellent.

- Pelaksanaan GUG harus tercermin dahulu pada setiap sikap dan tingkah laku pemberi layanan, sehingga apa yang akan dihasilkan dalam layanan dapat dirasakan mahasiswa. Perasaan tersebut yang nantinya dapat meningkatkan atau menurunkan kepercayaan mahasiswa terhadap Fakultas.

\section{Saran}

1) Fasilitas (Mushola dan Toilet) belum tentu dapat menjadi prioritas utama dalam pemberian layanan, karena bersifat sebagai pendukung. Namun apabila hal ini terus berlanjut tanpa adanya perbaikan dan tanggapan keluhan mahasiswa, aktivitas akademik pun akan terganggu.

2) Komunikasi antara dosen dan mahasiswa menjadi kunci lancarnya 
aktivitas akademik baik itu di dalam kelas maupun diluar kelas.

3) Untuk menguatkan kepercayaan, mahasiswa harus merasakan pelayanan akademik yang melebihi harapan mereka. Untuk itu excellent service dapat menjadi kunci peningkatan kepercayaan mahasiswa. Dan cara untuk menghasilkan excellent service adalah dengan menerapkan prinsipprinsip GUG dalam setiap pelaksanaan pelayanan, maupun sikap dan tingkah laku pemberi layanan.

4) Perlu adanya peningkatan peran satuan pengawas intern atau Tim Penjaminan Mutu ditiap-tiap fakultas ataupun perguruan tinggi. Semakin baik peran satuan pengawas intern tersebut maka semakin baik pula pencapain GUG untuk meningkatkan excellent service

\section{Batasan Penelitian}

1. Dalam Analisis data penelitian ini menggunakan format kuesioner tertutup yang tidak dilengkapi dengan kuesioner terbuka. Sehingga jawaban responden dikhawatirkan kurang obyektif

2. Obyek penelitian ini sangat terbatas, sehingga implikasi dalam penelitian tidak sepenuhnya akurat bila diterapkan pada fakultas lain maupun organisasi lainnya

\section{Agenda Penelitian yang Akan Datang}

1. Penelitian selanjutnya dapat menggunakan metode kualitatif dengan berberapa informan kunci yang kompeten dan ahli di bidangnya sehingga dapat lebih dalam lagi menggali informasi pelaksanaan GUG untuk meningkatkan excellent service dan menciptakan Trust

2. Penelitian selanjutnya dapat mengambil obyek penelitian yang lain diluar organisasi pendidikan atau tetap pada obyek yang sama namun dapat bersifat membandingkan antar fakultas yang satu dengan yang lainnya atau universitas satu dengan yang lainnya.

\section{DAFTAR PUSTAKA}

Antarwiyati, Prapti, dkk, "Determinan Electronic Loyalty (E-Loyalty) pada Website", Fakultas Ekonomi, Universitas Islam Indonesia, 2006

Anwar, Misbahul, "Penerapan Model Tata Kelola Keuangan Perguruan Tinggi yang Baik untuk Mewujudkan Good University Governance (Studi Pada PTM se Indonesia)", Universitas Muhammadiyah Yogyakarta, Yogyakarta, 2012

Dalimunthe, RF, "Analisis persepsi karyawan bagian administrasi umum tentang penerapan prinsip Good Corporate Governance (transparansi, akuntabilitas, keadilan, dan partisipasi) kaitannya dengan kinerja karyawan di Rumah sakit Umum Daerah dr. Zainoel Abidin Banda Aceh tahun 2009" Universitas Sumatera Utara, 2010

Fattah, Agung, R, "Konsep, dan hasil survey implementasinilai-nilai GUG di YPT Group", Yayasan Pendidikan Telkom, 2011

Firdayanti, Restika, "Persepsi Risiko Melakukan E-Commerce dengan Kepercayaan Konsumen dalam Membeli Produk Fashion Online", Journal of Social and Industrial 
Psychology, Universitas Negeri Semarang, 2012

Ghozali, Imam, "Structural Equation Modeling: Teori, Konsep, dan Aplikasi dengan Program Lisrel 8.80", edisi dua, BP UNDIP, Semarang, 2008

Jahroni, "Pengaruh Kualitas Layanan Terhadap Loyalitas Nasabah Melalui Kepuasan, Komitmen, Kepercayaan Pada Bank Central Asia Tbk", Jurnal Akuntansi, Manajemen Bisnis dan Sektor Publik (JAMBSP), Universitas Sunan Giri Surabaya, 2009

Joko Widodo, "Good Governance", Ihsan Cendikia, Surabaya, 2001

Keputusan Menteri Pendayagunaan dan Aparatur Negara (MenPAN), "Asas Pelayanan Publik dengan Prinsip-Prinsip Good Governance, Nomor 63/KEP/M.PAN/7/2003

Mansur, T, "Faktor-faktor yang Mempengaruhi Kualitas Pelayanan Publik pada Bagian Bina Sosial Setdako Lhokseumawe, Universitas Sumatera Utara, Medan, 2008

Meilianasari, Yeni Dwi, "Analisis Kepercayaan Nasabah Pengguna ATM, Jurnal Manajemen Bisnis, Vol. 2, Edisi April, Fakultas Ekonomi UMM, 2012

Muhi, Ali Hanapiah, "Membangun Good Governance pada Perguruan Tinggi di Indonesia", Institut Pemerintahan Dalam Negeri (IPDN), Jatinangor, 2010
Nugraha, dkk, "Analisis Pengukuran Kepuasan Mahasiswa terhadap Kualitas Layanan Akademik di Perguruan Tinggi", Prosiding SNAPP: Sains, Teknologi dan Kesehatan, 2012

Putri, Rizky Leonni, dkk, "Pengaruh Reputasi Negara Asal (Country of Origin Reputation) terhadap Kepercayaan (Trust) pada Pembeli Produk Elektronik Merek Changhong China, Jurnal Psikologi Industri dan Organisasi, Vol. 1 No. 02, Universitas Airlangga, 2012

Purwanto, Erwan, Agus, "Keluhan Sebagai Bentuk Partisipasi”, Jurnal Kebijakan dan Administrasi Publik (JKAP), Sekolah Pasca Sarjana Universitas Gajah Mada, Magister Administrasi Publik, Vol12, Yogyakarta, 2008

Rahmayanty, N, "Manajemen Pelayanan Prima", Graha Ilmu, Yogyakarta, 2010

Rofiq, Ainur, "Pengaruh Dimensi Kepercayaan (Trust) terhadap Partisipasi Pelanggan E-Commerce (Studi Pada Pelanggan ECommerce Di Indonesia)", Fakultas Ekonomi Universitas Brawijaya, Malang, 2007

Rukmi, Hendang Setyo, dkk, "Usulan Perbaikan Kualitas Layanan Pendidikan Tinggi Menggunakan Metode Student Satisfaction Inventory (Studi Kasus PTS X)", Proceeding Seminar Nasional IV Manajemen \& Rekayasa Kualitas, 2010 
Sentana, A, "Excellent Service \& Customer Satisfaction". PT Elex Media Komputindo, Jakarta, 2006

Sudarmanto, Gunawan, "Good University Governance: Pemahaman Pengertian dan Bagaimana Seharusnya Implikasi dalam Penyelenggaraan Perguruan Tinggi, ITB, Bandung, 2011.

Wiyogo, dkk, "Integrasi Servqual dan Quality Function Deployment untuk Pengukuran Kualitas Layanan (Studi Kasus: Program Studi Pendidikan Teknik Mesin, Universitas Palangka Raya)", JEMIS, Vol. 1, No. 1, Universitas Brawijaya, Malang, 2013

Yenny, "Prinsip-Prinsip Good Governance Studi Tentang Penerapan Prinsip-Prinsip Good Governance Dalam Pelaksanaan Pelayanan Publik di Kantor Camat Samarinda Utara Kota Samarinda", eJournal Ilmu Administrasi Negara, 2013 